Through the efforts of our various agencies for health with their campaigns for public education, the number of individuals who appreciate the value of such supervision as I have outlined is daily increasing.

The success of my own endeavors leads me to believe that there is a decided need for specialists in this line.

\section{THE QUESTION OF DRAINAGE IN CHOLECYSTECTOMY.*}

BY John T. BotTomLey, M.D., F.A.C.S., Boston.

This brief communication is presented as the forerunner of a more extensive future paper which will be based on a wider experience in the field under consideration. It is offered now because it represents the first results of a change made in my surgical practice and because I desire your comment on and criticism of the matter in question.

It will be granted, I assume, that where drainage is contraindicated or inadvisable its use is either harmful or unnecessary. For the past decade or two the tendency has been to limit or to do away entirely with the use of drainage in abdominal cases. We may cite as witnesses the facts that not a few surgeons now use no drainage after reasonably early operation for perforation of a gastric or duodenal ulcer, that many men no longer use drainage as a means of carrying off the serous effusion accompanying acute appendicitis and that many pelvic cases now go undrained which would certainly have been drained some years ago. Mast of us older men can remember the days when abdominal drainage meant huge wads of gauze packing sticking out of the abdominal wounds and making necessary great suffering and often serious shock in their removal. Today a split rubber tube carrying gauze, or a cigarette drain suffices in most instances. It is in the field of biliary surgery that we have made relatively little ehange in our methods of drainage. Crile, it is true, has called attention to the fact that it is not necessary to drain the common duct after the removal of stones, provided that one is sure that the duct is patent. "Why drain a drain?" he tersely puts it. His advice and example have led others at least to consider the advisability of keeping drains out of the common duct whenever that procedure

* Read at the meeting of The Boston Surgical Society, April 5, seems wise, and I think it has seemed wise in a gradually increasing number of cases. Yet it is in the more simple and the less threatening part of the field of biliary surgery that the use of drainage has been continued almost without exception and without much change in methed for many years. Occasionally a gall bladder was explored or a few stones removed from it and the gall bladder was closed at once. This practice, however, was so rare as to be almost negligible. I can see a good reason for its nonacceptance as a routine measure even in simple, uncomplicated cases, because a satisfactory exploration of the interior of the gall bladder is practically impossible without removing it and one fears to shut in the unknown which may, perhaps, be dangerous. However, it seems to me that in the matter of cholecystectomy we have held sacred for too long a time the need of drainage. I feel that in a very large number of these cases drainage either might be entirely dispensed with or might be provided for a far shorter time than was usually customary. Isate in December I began to close many of my cholecystectomy cases tightly without drainage of any kind and it is the object of my brief communication this evening not only to call your attention to this practice but also to note its results. Of course, the disuse of drainage means careful dissection and separate ligation of the cystic duct and the cystic vessels and careful hemostasis applied to the bed of the gall-bladder in the liver. The cystic duct and the cystic artery have always been tied separately with No. 1 chromic eatgut, the stump of the cystic duct has always been sterilized and its end protected by a tab of fat from the neighboring gastrohepatic omentum. The deep field of operation has usually been cleansed with gauze saturated with ether. The folds of peritoneum dissected off the gall bladder need not be sutured over the denuded area in the liver but may simply be laid on it. Slight oozing in the liver is controlled by hot packs applied temporarily or by laying omentum against the oozing surface. I have regarded moderate persistent oozing that I could not entirely control as a contraindication to the disuse of drainage; in such instances, drainage has been provided for a few hours (24-36). Cases, too, in which there has been a good deal of soiling from an apparently infected gall bladder should be protected by drainage. 
In the last three months I have done fifteen cholecystectomies without providing drainage of any kind. One patient died; she was a fat, elderly woman, with a huge umbilical hernia which had been long incarcerated and had occasionally given rise to bothersome symptoms. In the course of the operation I found a contracted gall bladder full of stones and very adherent to the duodenum. I finished the operation for the umbilical hernia and then foolishly, through another incision, removed the gall bladder. There was an old perforation between the gall bladder and the duodenum which necessitated a suture of the duodenum. This patient died, probably of peritonitis, on the third day. The other fourteen cases were eminently successful from every point of view. In one case a small hematoma of the abdominal wall was opened at the end of the first week and healed immediately. In another case in which I did a cholecystectomy for a persistent sinus following a previous cholecystectomy, a little serum was evacuated from the top of the wound on the thirteenth day, though I drained the abdominal wall temporarily because of the presence of the sinus. These cholecystectomies were done for cholecystitis both acute and chronic, both with and without stones. In five other cases a cigarette drain or a bit of rubber dam was left in for 24 to 36 hours and then removed. These cases also did very well and the wounds healed kindly. These twenty cholecystectomies have been done with no drainage or one of short duration. There has been absolutely no leakage of bile and the convalescence has been very comfortable.

These cases represent exactly two-thirds of my biliary surgery during the time in which they occurred.

I was led to the adoption of this procedure by the fact that a good portion of my operative wounds in biliary surgery, especially in fat people, became. somewhat infected after draining for several days and that some developed troublesome hernias after operation. It is almost impossible to keep clean a wound drained onto the skin. These wounds often beeome infected despite all eare and a weak abdominal wall is the result.

I realize that twenty cases are far too small a number from which to draw a general conclusion. I am working with an open mind and am just as willing to discontinue this practice, if I find I am subjecting patients to undue risk, as I am to continue it, if things go well. If the disuse of drainage is safe in most of the cases of cholecystectomy, certainly drainage should be done away with. As with all other things in surgery, the matter requires judgment; it requires judgment to know whether or not to drain after an operation for appendieitis. It is no different in the field of biliary surgery.

\section{Jledical Jrongegs}

\section{REVIEW OF RECENT LITERATURE ON TUBERCULOSIS.}

By John B. Hawes, M.I)., Boston:

T'HE amount of literature published during the past year or more on the general subject of tuberculosis is enormous. It is manifestly impossible to review or even to refer to each article on this subject. I have, therefore, confined myself to what appear to ne to be the more important ones. These articles naturally fall into certain groups, chief among which are: (1) Tuberculosis and the War; (2) Tuberculosis and Influenza; (3) The Framingham Experiment; (4) The Tuberculosis Campaign, and (5) Miscellaneous Articles on Tuberculosis.

\section{TUBERCULOSIS AND THE WAR.}

Before we entered the war, alarming reports reached this country concerning the enormous amount of tuberculosis among the French troops and the distressing frequency of exacerbations of this disease due to war conditions. Bushnell (J.A.M.A., June 18, 1918, Vol. LXX, No. 24, 1821), in a careful article, was among the first to point out the exaggeration in these statements. France apparently lost the services of nearly 80,000 men on account of a wrong diagnosis of tubereulosis. Miller (Rev. of Tuberculosis, August, 1919, Vol. III, No. 6) confirms Bushnell's statements and gives a clear picture of what the tuberculosis problem in $\mathrm{Eu}$ rope really amounts to. Hatfield (Boston M. \& S. J., June 20, 1918, Vol. chxtrviIr, No. 25, 863) reviews this subject from the American viewpoint with special reference to the soldier rejected on account of this disease. Badnel \& Mendes (Policlin., May 26, 1918, Vol. Xxv, No. 21, 492), and Maragliano (Rif. Med., April 27, 1918, Vol. xxxIv, No. 17, 332) deseribe this subject as it appears among Italian troops. 